\title{
Assessment of Physical and Mechanical Properties of Polyurethane as Ground Improvement Material for Peat
}

\author{
Mohamad Niizar Abdurahman \\ Public Works Department of Malaysia \\ Kuala Lumpur, Malaysia \\ mniizar@jkr.gov.my
}

Adnan Zainorabidin and Kasbi Basri

Research Center for Soft Soil (RECESS) / Faculty of Civil Engineering and Built Environment

Universiti Tun Hussein Onn Malaysia

Johor, Malaysia

adnanz@uthm.edu.my

Azman Kassim

School of Civil Engineering, Faculty of Engineering

Universiti Teknologi Malaysia

Johor, Malaysia

azmankassim@utm.my

\begin{abstract}
Peat is considered problematic soil due to its large void ratio, high compressibility and low shear strength. Various ground improvement methods have been developed in recent years to improve peat's strength properties. Polyurethane grouting is one of the ground improvement methods that is gaining recognition as effective and fast way to stabilize soil. Polyurethane is a lightweight material produced by mixing polyol and isocyanate chemicals. Upon mixing, a polyurethane foam is created which expands up to a few times of its original volume. In this study, the strength characteristics of polyurethane with different mix ratios of polyol to isocyanate were evaluated to determine the optimum ratio suitable to be used to stabilize peat. Polyol to isocyanate ratio of 1:1, 1:1.5, 1:1.2, 1:2.5 and 1:3 were tested in this this research. The propagation, microstructure and density of polyurethane were investigated. Compressive strength of polyurethane determined using Unconfined Compression Strength test. Polyurethane created with higher ratio of isocyanate bears higher density and compressive strength compared to the polyurethane with lesser quantity of isocyanate. The cell structure of the polyurethane also is smaller with thicker cell walls. However, the curing time consumed by the polyurethane with high ratio of isocyanate is 8 times greater than the normal polyurethane. Thus, polyurethane ratio with fast curing time and high compressive strength was chosen as the optimum mix ratio to be used to stabilize peat.
\end{abstract}

\section{Keywords}

Peat, ground improvement, grouting, polyurethane, compressive strength

\subsection{Introduction}

Peat covers up to $8 \%$ of total land area in Malaysia with $69.08 \%$ of it in Sarawak, $26.16 \%$ in Peninsular Malaysia and $4.76 \%$ in Sabah [1]. Peat is considered as one of the major groups of soil found in Malaysia [2]. Peat is often reflected as a problematic soil due to its high compressibility, low shear strength, high natural moisture content and void ratio. Various ground improvement methods have been developed to improve peat strength properties to make it more suitable for construction. Some of the methods are mentioned in Table 1. 
VOLUME 20 | NUMBER 2 | January 2021 https://ejournal.worldconference.id/index.php/neutron E-ISSN: 2685-3272 | P-ISSN 1412-0860

Table 1: Ground improvement methods applicable on peat [3-5]

\begin{tabular}{lll}
$\begin{array}{l}\text { Construction } \\
\text { Technique }\end{array}$ & \multicolumn{1}{c}{ Method } \\
\hline & $\bullet$ & Stone column \\
& $\bullet$ & Cement column \\
& $\bullet$ & Soil column \\
Ground Improvement & $\bullet$ & Grouting \\
& Prefabricated vertical \\
& drains & Ground freezing \\
& - & Dynamic compaction \\
& - Vibro compaction \\
& - Chemical modification \\
\hline
\end{tabular}

Grouting method usually refers to the injection of suspensions, solutions and emulsions into the pores in soils to improve the geotechnical characteristics, particularly strength of the soil. According to Mitchell \& Jardine (2002), grouting can increase strength, stiffness and bearing capacity of ground, to reduce permeability of ground, to provide a barrier or cut-off to water flow in the ground, increase strength of ground for its safe excavation, increase overall density of ground, infill cavities, infill mineral workings, infill voids adjacent to structures and compensate ground loss due to adjacent works [4]. Grouting is a versatile method that can be used due to its wide ranges of method namely permeation grouting, claquage grouting, compaction grouting and jet grouting and grout materials [6]. Table 2 summarizes different type of grout materials available in the market.

Table 2: Materials of grout [4]

\begin{tabular}{lc}
\hline Type of grout & Material \\
\hline $\begin{array}{l}\text { Cement based } \\
\text { grout }\end{array}$ & Cement slurry \\
& Cement mortar \\
& Cement-bentonite mixture \\
\hline Chemical grout & Silicates \\
& Lignin compound \\
& Phenolic resin \\
& Acrylic resin \\
Polyurethane
\end{tabular}

Polyurethane (PU) was first made by Otto Bayer in 1937. However, it was first used as a grouting material starting in 1980s in the mining industry and in the recent years the usage has spread significantly to civil and geotechnical application [11]. Currently, the PU grouting is widely used in the fields of underground constructions and tunneling, mining, geotechnical works, water management, bridges and road [11]. PU is produced by mixing two polymers which are polyol and isocyanate [17]. The mixture then creates PU foam that expands a few times of its original volume. PU is a lightweight material and very suitable to be used to treat soil because no excessive overburden pressures were put on the treated soil [13]. Cured PU foam can have compressive strength between $468 \mathrm{kPa}$ to $689 \mathrm{kPa}$ [18]. This research was carried out to evaluate strength characteristic of $\mathrm{PU}$ and to determine optimum ratio of PU suitable to be applied as a grout material in peat.

\subsection{Methodology}

The polyurethane (PU) foams were produced by mixing the polyol and isocyanate as shown in Figure 1. The polyol and isocyanate were mixed in different ratios to determine the optimum ratio to be used to stabilize peat. Ratios between polyol to isocyanate tested in this research are 1:1, 1:1.5, 1:2, $1: 2.5$ and 1:3. Mix ratio 1:1 is the current practise of the supplier at site and considered as baseline. 


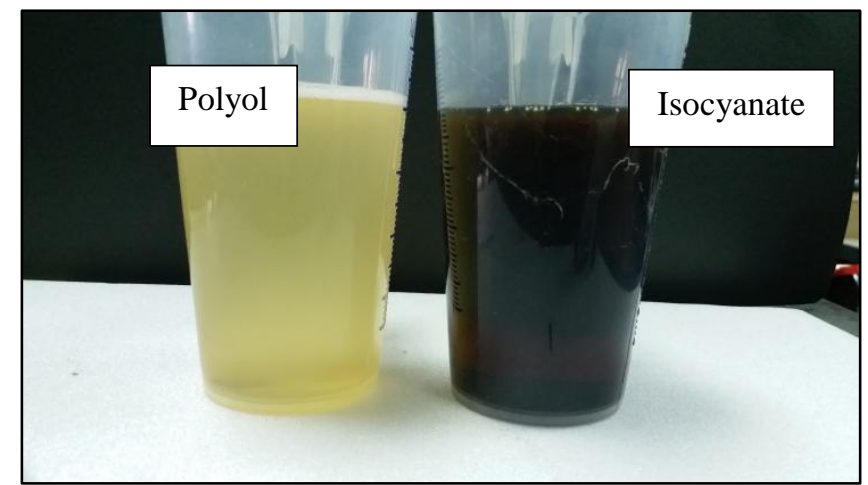

Figure 1: Polyol and isocyanate used to produce PU foam

\subsection{Propagation}

The aim of this experiment was to investigate and observe the PU propagation and expansion mechanism. This was done by mixing the PU into one end of a clear cylinder mould and allowing it to propagate freely. The moulds used are made of Perspex, with one end fixed with cap and the other end left open. A digital camera mounted on a tripod was used to record the propagation process. The cream time (time between start of mixing and the point at which fine bubbles begin to appear), rise time (the time at which the foam stops expanding as observed visually), tack time (the time at which the surface of the foam can be touched with a gloved finger without sticking) and gel time (the time at which the foam hardened fully and be taken out of the mould) are recorded. The rise time was recorded at every $50 \mathrm{~mm}$ expansion of PU and the whole process were video graphed using the camera. Finally, the time dependent one-dimensional PU expansion process was assessed.

\subsection{The Micro-structure of PU}

The PU samples of every ratio were sliced and inspected using microscope camera to study the cellular structures. Microscopic photographs of PU samples were recorded at plan view and at the direction of rise.

\subsection{Density}

PU foams were produced in batches using the Perspex mould. After 24 hours, the foams then were trimmed to the dimension of $50 \mathrm{~mm}$ diameter and $100 \mathrm{~mm}$ height with smooth surface at both ends. The trimmed samples were weighed and calculated for their density.

\subsection{Unconfined Compressive Strength (UCS) Test}

The strength characteristics of PU are determined by Unconfined Compressive Strength (UCS) test. The tests were conducted in accordance to ASTM D1621. The sample size for this test is $50 \mathrm{~mm}$ in diameter and $100 \mathrm{~mm}$ in length. Every samples were tested until $50 \%$ strain. Fig. 2 shows the equipment used for this test. Total of 9 samples were tested for UCS for every PU ratio.
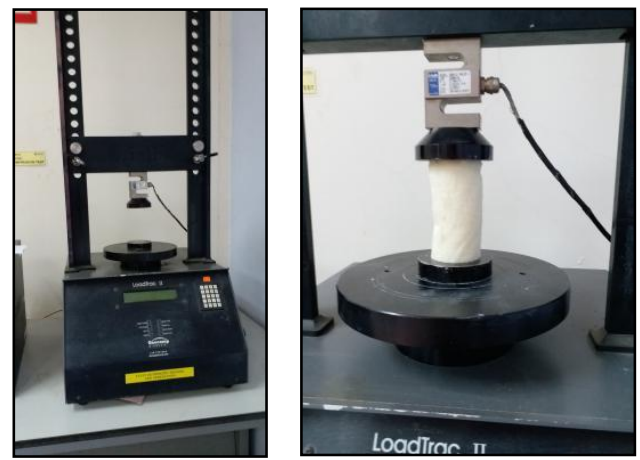

Fig. 2: Equipment used for Unconfined Compressive Strength (UCS) test, (a) Geocomp UCS test machine; (b) PU sample subjected to UCS test 


\subsection{Water absorption}

The method of Sasaki (2008) was adopted for this test with modification where the prepared PU samples were soaked in peat water collected from Parit Nipah, Johor. The PU samples were weighed and recorded daily. This test only completed when a constant value of weight is achieved which indicates no more water absorption by samples.

\subsection{Results and Discussion}

\subsection{Propagation}

Table 3 shows the average propagation time recorded for PU according to the tested different mix ratios. The cream time for all mix ratio were same where the chemicals began to react within 3 seconds after mixing. However, the rise time, tack time and gel time, the duration taken is increased with the increasing ratio of isocyanate. For PU samples ratio 1:1, 1:1.5 and 1:2, the gel time taken where the samples are hardened completely was less than 7 minutes. For the ratio of 1:2.5, it took almost 30 minutes and for the ratio of $1: 3$, it took more than 60 minutes. Figure 3 shows clearly that the PU samples with mix ratio 1:2.5 and 1:3 took 8 times set compared to the other mix ratios. The result indicates that the increment of isocyanate ratio increases the time required for the PU to fully set and hardened.

Table 3: Average propagation of PU according to mix ratio

\begin{tabular}{|c|c|c|c|c|c|}
\hline \multicolumn{3}{|c|}{ FPU Ratio } & \multicolumn{4}{c|}{ Propagation Time (s) } \\
\hline Polyol & Isocyanate & Cream Time & Rise Time & Tack Time & Gel Time \\
\hline 1 & 1 & 3 & 190 & 248 & 258 \\
\hline 1 & 1.5 & 3 & 202 & 257 & 383 \\
\hline 1 & 2 & 3 & 220 & 340 & 428 \\
\hline 1 & 2.5 & 3 & 255 & 392 & 1709 \\
\hline 1 & 3 & 3 & 326 & 505 & 4172 \\
\hline
\end{tabular}

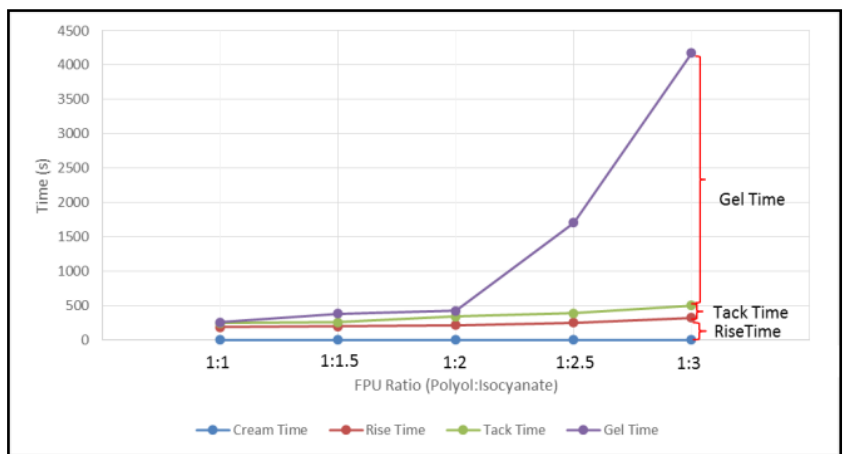

Figure 3: Average propagation time of PU against mix ratio

Figure 4 shows that during rise time which occurs after cream time, the propagation of all PU samples was similar until the distance of $150 \mathrm{~mm}$. Then, the expansion of PU sample of $1: 3$ ratio was noticed got slower than other PU samples. During the transition period from rise time to tack time, the expansion rates of all samples were slower compared to earlier stage. At this stage, the chemical reaction was almost completed, and the foam gradually stops from any further expansion.

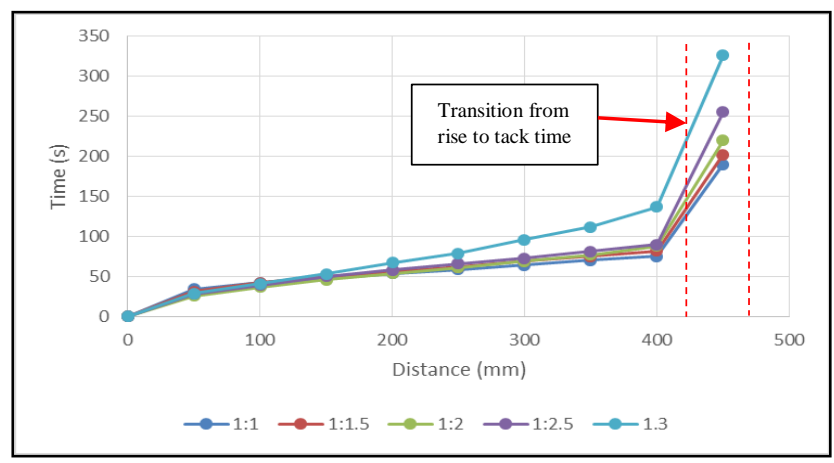

Figure 4: Propagation of different ratio of PU against time 
VOLUME 20 | NUMBER 2 January 2021 https://ejournal.worldconference.id/index.php/neutron E-ISSN: 2685-3272 | P-ISSN 1412-0860

Figure 5 shows the expansion of PU recorded at every $100 \mathrm{~mm}$ interval. Final height of PU was approximately $450 \mathrm{~mm}$ after rise time. The shortest rise time of 190 seconds and longest rise time of 326 seconds recorded for PU with ratio $1: 1$ and 1:3 respectively.

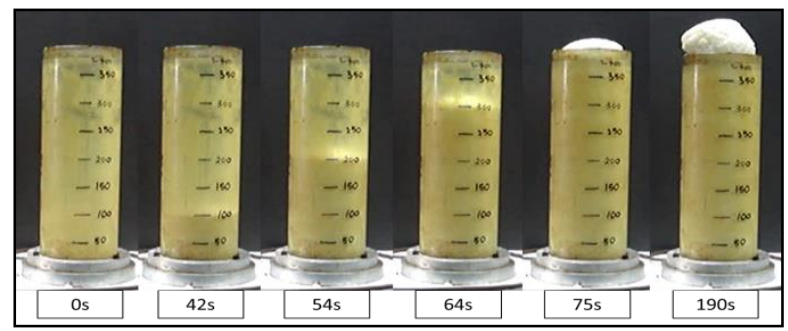

(a)

Figure 5: Propagation of different ratio of PU against time recorded at every $100 \mathrm{~mm}$ interval, (a) PU 1:1; (b) PU 1:1.5; (c) PU 1:2; (d) PU 1:2.5 and (e) PU 1:3

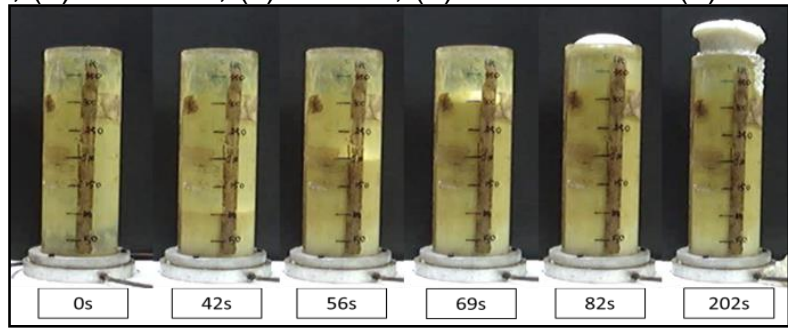

(b)

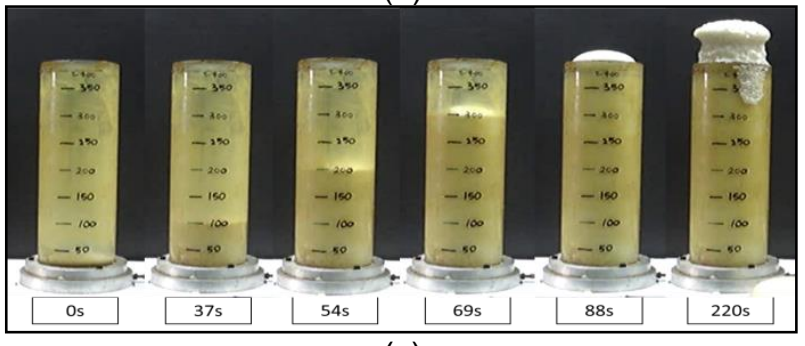

(c)

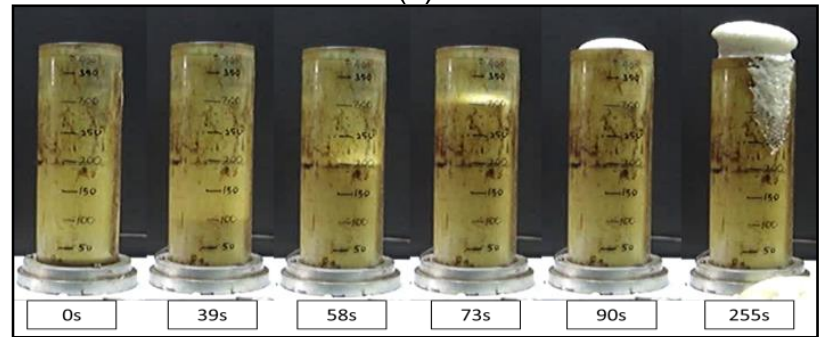

(d)

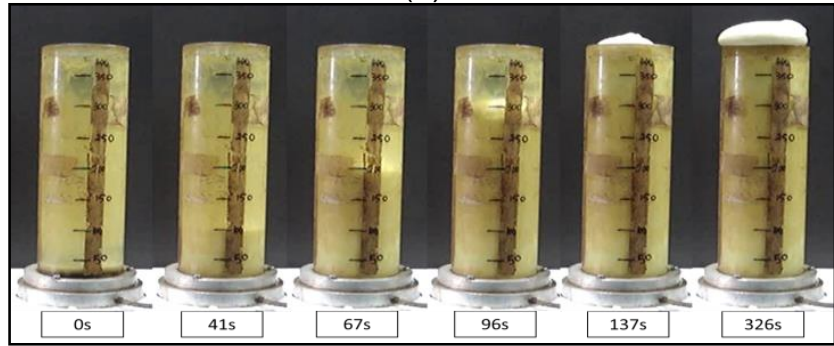

(e)

Figure 5: Propagation of different ratio of FPU against time recorded at every $100 \mathrm{~mm}$ interval, (a) PU 1:1; (b) PU 1:1.5; (c) PU 1:2; (d) PU 1:2.5 and (e) PU 1:3 (continued)

Figure 6 shows that the velocity of PU kept increasing until the transition period from rise to tack time. During this period where the velocity was reduced by half. Figure 6 also summarizes that with addition of isocyanate, it gradually reduces the expansion velocity of PU. 
VOLUME 20 | NUMBER 2 | January 2021

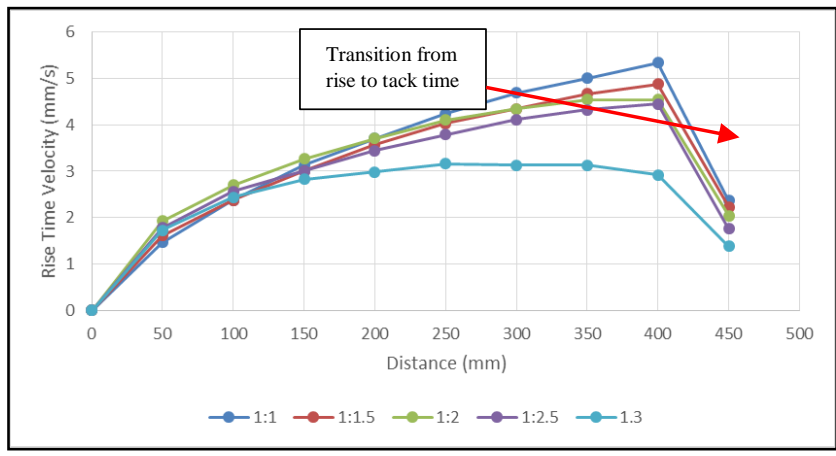

Figure 6: Velocity of PU

\subsection{Micro-structure study}

From Figure 7, it can be confirmed that the PU is a closed cell PU. Closed cell indicates that gases produced during expansion of PU are still trapped in the cells thus making lighter and less dense. The microscopic picture shows that polygonal cell size was larger for PU with ratio 1:1 compared to PU with ratio 1:3. This happened because with lesser quantity of polyol, less gases were released during expansion of the PU. Thus, making the cell walls thicker. These attributes will make the PU with higher isocyanate ratio to be very rigid and denser. The same condition is noticed on the cells in the rise direction as shown in Fig. 8. The cell size of PU ratio 1:1 is larger with thin cell walls compared to the cell structure of $\mathrm{PU}$ ratio 1:3.

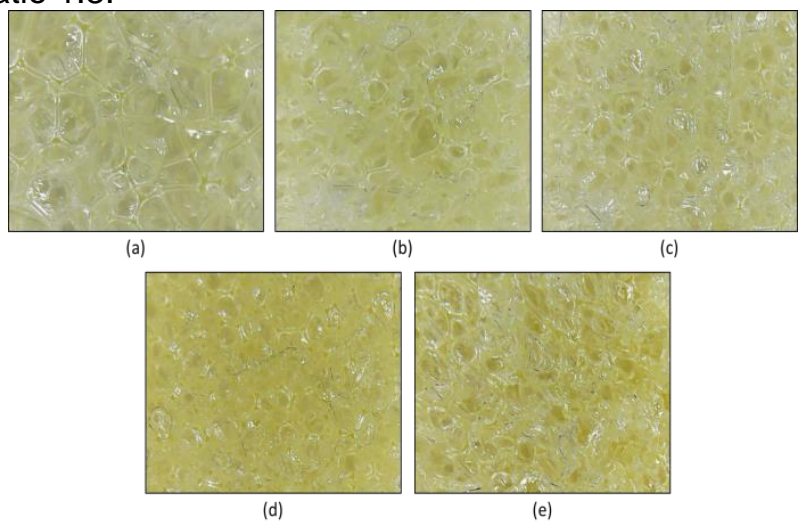

Figure 7: Microscopic picture (x100) of closed cell molecule of PU according to polyol to isocyanate ratio - plan view, (a) 1:1; (b) 1:1.5; (c) 1:2; (d) 1:2.5 and (e) 1:3

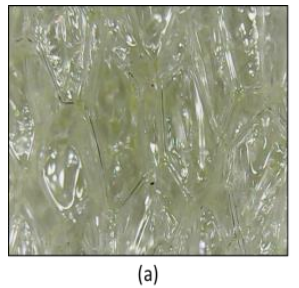

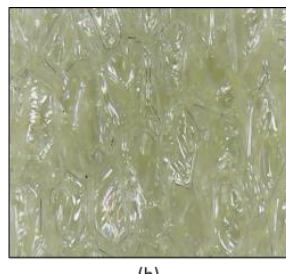

(b)

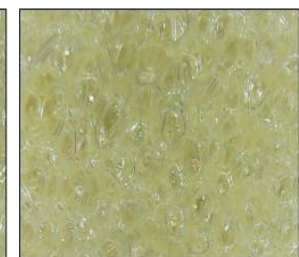

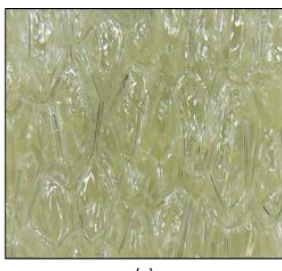

(c)

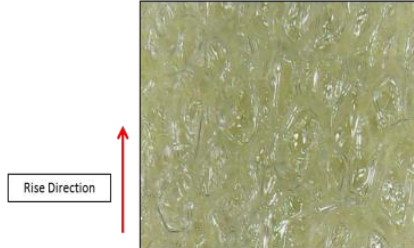

(d) (e)

Figure 8: Microscopic picture ( $\mathrm{x} 100)$ of closed cell molecule of PU according to polyol to isocyanate ratio - rise direction, (a) 1:1; (b) 1:1.5; (c) 1:2; (d) 1:2.5 and (e) 1:3

\subsection{PU density}

The overall PU density documented in this research ranges between $6.9 \mathrm{~kg} / \mathrm{m}^{3}$ and $26.5 \mathrm{~kg} / \mathrm{m}^{3}$ as mentioned in Table 4. The average density of PU for ratio $1: 1,1: 1.5,1: 2,1: 2.5$ and $1: 3$ is $6.9 \mathrm{~kg} / \mathrm{m}^{3}$, $8.4 \mathrm{~kg} / \mathrm{m}^{3}, 13.0 \mathrm{~kg} / \mathrm{m}^{3}, 18.1 \mathrm{~kg} / \mathrm{m}^{3}$ and $26.0 \mathrm{~kg} / \mathrm{m}^{3}$ respectively. By increasing the isocyanate quantity, it 
VOLUME 20 | NUMBER 2 | January 2021 https://ejournal.worldconference.id/index.php/neutron E-ISSN: 2685-3272 | P-ISSN 1412-0860

is found that the density of the PU also increases exponentially. As explained in 3.2, smaller cellular sizes and thick cell walls generated during expansion influence directly the density of PU.

Table 4: PU density ranges

\begin{tabular}{|c|c|c|}
\hline $\begin{array}{c}\text { FPU Ratio } \\
\text { (Polyol:Isocyanate) }\end{array}$ & $\begin{array}{c}\text { Density Range } \\
\left(\mathrm{kg} / \mathrm{m}^{3}\right)\end{array}$ & $\begin{array}{c}\text { Average Density } \\
\left(\mathrm{kg} / \mathrm{m}^{3}\right)\end{array}$ \\
\hline $1: 1$ & $6.9-7.0$ & 6.9 \\
\hline $1: 1.5$ & $8.0-8.7$ & 8.4 \\
\hline $1: 2$ & $12.0-13.7$ & 13.0 \\
\hline $1: 2.5$ & $17.5-19.9$ & 18.1 \\
\hline $1: 3$ & $25.0-26.5$ & 26.0 \\
\hline
\end{tabular}

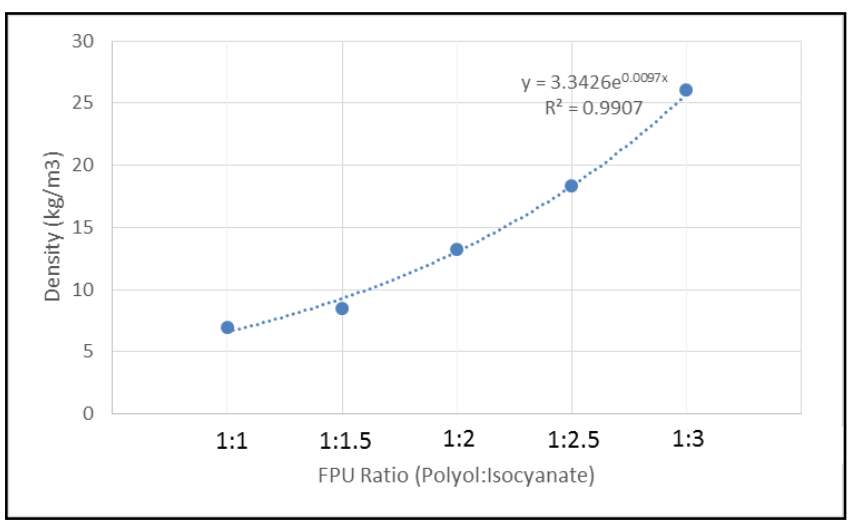

Figure 9: Average density of PU according to mix ratio

\subsection{Compressive strength}

Table 5 shows the compressive strength of PU tested at laboratory. As per density, Figure 10 indicates that the compressive strength of $\mathrm{PU}$ also increases exponentially with the increment of isocyanate ratio. The compressive strength ranges between $65 \mathrm{kPa}$ to $750 \mathrm{kPa}$ with average compressive strength of $\mathrm{PU}$ for ratio $1: 1,1: 1.5,1: 2,1: 2.5$ and $1: 3$ is $89 \mathrm{kPa}, 184 \mathrm{kPa}, 220 \mathrm{kPa}, 297 \mathrm{kPa}$ and $590 \mathrm{kPa}$ respectively. The minimum compressive strength of FPU recorded is still higher if compared to compressive strength of remoulded peat which is $22 \mathrm{kPa}$ [19]. For PU ratio 1:2.5 and 1:3, even though the compressive strength is high, but the samples are brittle. It can withstand against stress but does not withstand with much elongation before fail.

Table 5: PU compressive strength ranges

\begin{tabular}{|c|c|c|}
\hline FPU Ratio & $\begin{array}{c}\text { Compressive } \\
\text { Strength Range } \\
(\mathrm{kPa})\end{array}$ & $\begin{array}{c}\text { Average Compressive } \\
\text { Strength } \\
(\text { Polyol:Isocyanate) }\end{array}$ \\
\hline $1: 1$ & $65-115$ & 89 \\
\hline $1: 1.5$ & $150-195$ & 184 \\
\hline $1: 2$ & $170-245$ & 220 \\
\hline $1: 2.5$ & $200-400$ & 297 \\
\hline $1: 3$ & $500-750$ & 590 \\
\hline
\end{tabular}

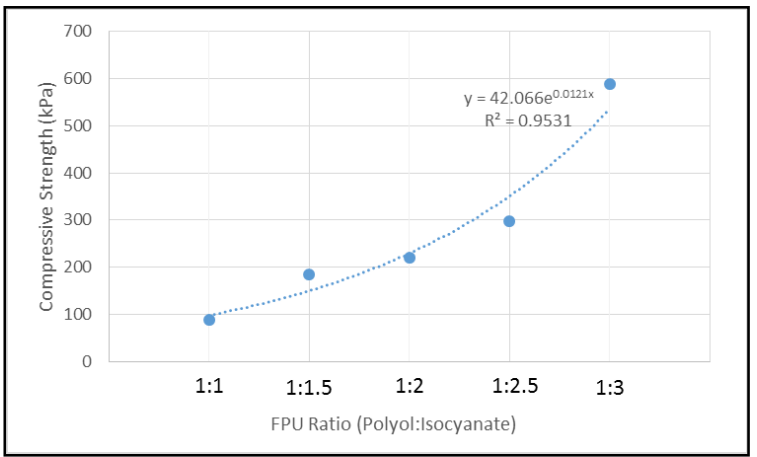

Figure 10: Average compressive strength of PU according to mix ratio 
VOLUME 20 | NUMBER 2 | January 2021

Figure 11 shows that the elastic modulus of $\mathrm{PU}$ increases with higher ratio of isocyanate. The elastic modulus for PU 1:1, 1:1.5, 1:2, 1:2.5 and $1: 3$ is $27 \mathrm{MPa}, 56 \mathrm{MPa}, 79 \mathrm{Mpa}, 124 \mathrm{MPa}$ and $163 \mathrm{Mpa}$ respectively. Higher elastic modulus shows that the material is more rigid and brittle.

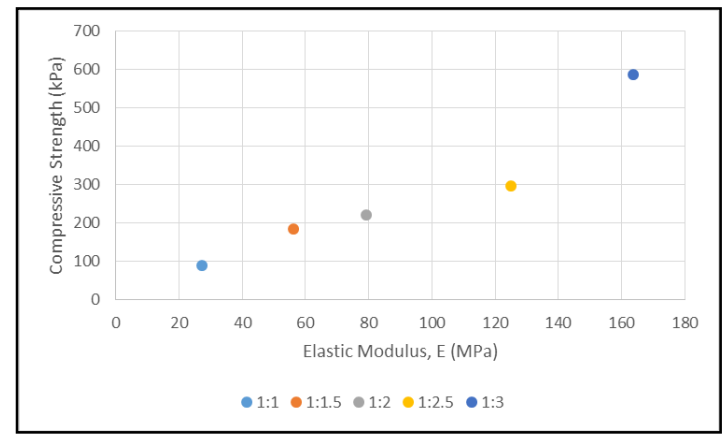

Figure 11: Average elastic modulus of PU

Figure 12 points that the higher compressive strength is achieved when the gel time of PU is higher. It shows that PU samples that can withstand higher stress needs longer duration to be hardened. Even if the compressive strength achieved is high but waiting a long time for the PU to harden does not meet the special characteristics of PU grouting that edges other grout material which is fast curing.

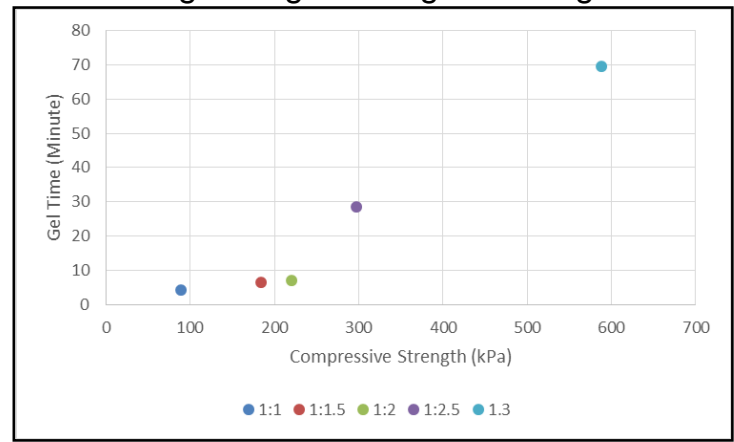

\subsection{Water absorption}

Figure 12: Compressive strength of PU against gel time

PU samples were soaked completely for almost 30 days in peat water to evaluate its absorption behaviour. PU with less density tend to absorb more water in longer duration compared to PU with higher density. Figure 13 shows that PU ratio 1:1 can absorb up to $304 \%$ water compared to its initial condition. The PU kept absorbing water until the 14day. Same pattern was discovered with PU ratio 1:1.5. But for FPU ratio 1:2, 1:2.5 and 1:3, the samples absorbed water only for 7 days before the weight becomes constant.

\subsection{Conclusion}

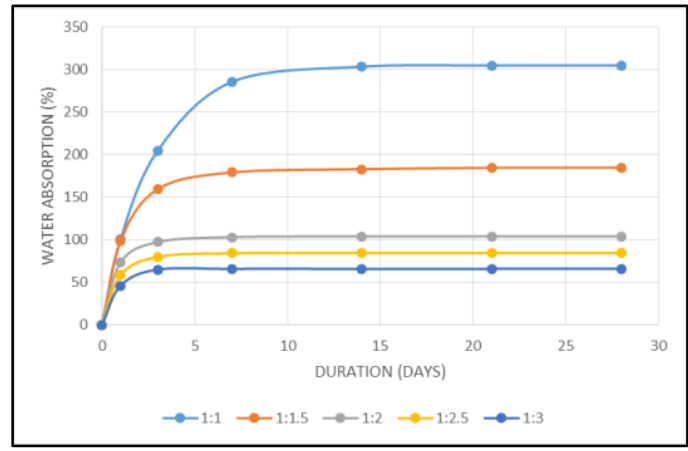

Figure 13: Water absorption by PU

Based on the review of experimental results, the following conclusions were attained:

1. Polyol to isocyanate mix ratio of $1: 2$ is the optimum mix ratio PU with high compressive strength and short gel time.

2. Higher ratio of isocyanate in PU results in higher compressive strength and makes it more rigid but brittle beyond the maximum stress.

3. The density and weight of PU increases with the addition of isocyanate in the mixture.

4. The cellular size of PU gets smaller and more compacted when the density of PU increases. 
VOLUME 20 | NUMBER 2 | January 2021 https://ejournal.worldconference.id/index.php/neutron E-ISSN: 2685-3272 | P-ISSN 1412-0860

5. Water absorption of PU decreases with the increment of its density.

\section{Acknowledgement}

The author would like to convey his appreciation to the Public Works Department (PWD) of Malaysia. Special thanks to Research Center for Soft Soil (RECESS) and Research on Peat Station (REPEATS) for the support and testing facilities provided.

\section{References}

[1] Wetlands International, A Quick Scan of Peatlands in Malaysia, Wetlands International Malaysia, (2010)

[2] Razali S.N.M, Zainorabidin A, Bakar I, Saedon N, Abdurahman MN \& Mokhtar M, Shrinkage Behavior Of Peat - Polymer Mixtures, International Journal of Recent Technology and Engineering (IJRTE), Blue Eyes Intelligence Engineering \& Sciences Publication , 7, 30, ISSN:22773878 (2019).

[3] Zainorabidin A, Abdurahman MN, Kassim A, Azlan MFMD, Razali SN \& Rahman ESEA, Settlement Behaviour of Parit Nipah Peat under Static Embankment, International Journal of Geomate, Vol,17, Issue 60, (2019), pp. 151-155. https://doi.org/10.21660/2019.60.8263

[4] Mitchell JM \& Jardine FM, A Guide to Ground Treatment, Construction Industry Research and Information Association, Department of Trade and Industry, London, UK, (2002).

[5] Huat BBK, Prasad A, Asadi A \& Kazemian S, Geotechnics of Organic Soils and Peat, CRC Press, Taylor \& Francis Group, London, UK, (2014).

[6] Bell FG, Engineering Treatments of Soils, E\&FN SPON, Chapman \& Hall, London, UK, (1993), pp:202-239.

[7] Lat DC, Jais IBM, Mohammed K, Baharom B, Samat N \& Zainuddin AN, Evaluation of Strength Characteristics for Palm Kernel Oil- Based Polyurethane (PKO-P) as a Ground Improvement Method, Malaysian Journal of Fundamental and Applied Sciences, Vol.12, No.4, (2016), pp.126129.

[8] Sasaki Y, Characterisation of Expanded Polymer Resin and Expansive Soil Composites, Master Thesis, University of Newcastle, Australia, (2008).

[9] Yenco A, Decision Tree for Ground Improvement in Transportation Applications, Master Thesis, University of Akron, USA, (2013).

[10] Buzzi O, Fityus S, Sasaki Y \& Sloan S, Structure and Poperties of Expanding Polyurethane Foam in the Context of Foundation Remediation in Expansive Soil, Mechanics of Materials, Vol.40, (2008), pp.1012-1021.

[11] Bodi J, Scucka J, Martinec P \& Bodi Z, Polyurethane Grouting Technologies, INTECH Open Access Publisher, (2012), pp:307-336.

[12] Akindoyo JO, Beg MDH, Ghazali S, Islam MR, Jeyaratnam N \& Yuvaraj AR, Polyurethane Types, Synthesis and Applications - A Review, The Royal Society of Chemistry, Adv., 6, (2016), pp:114453-114482, http://dx.doi.org/10.1039/c6ra14545f

[13] Samat NA, Jais IBM, Lat DC, Baharom B \& Salleh MA, Strength of Palm Kernel Oil-Based Polyurethane Foam/Resin as Alternative Method for Ground Improvement, ARPN Journal of Engineering and Applied Sciences, Vol.12, No.23, (2017), pp.6611-6615

[14] ASTM D7487-18, Standard Practice for Polyurethane Raw Materials: Polyurethane Foam Cup Test, ASTM International, West Conshohocken, PA, (2018).

[15] ASTM D1621-16, Standard Test Method for Compressive Properties of Rigid Cellular Plastics, ASTM International, West Conshohocken, PA, (2016).

[16] ASTM D2842-12, Standard Test Method for Water Absorption of Rigid Cellular Plastics, ASTM International, West Conshohocken, PA, (2012).

[17] Sharmin E \& Zafar F, Polyurethane: An Introduction, INTECH Open Access Publisher, (2012), $\mathrm{pp}: 1-16$.

[18] Yu L, Wang R \& Skirrow R, The Application of Polyurethane Grout in Roadway Settlement Issues, Proceedings of Geo Montreal 2013, Montreal, QC, Canada (2013).

[19] Kalantari B \& Huat BKK, Improving Unconfined Compressive Strength of Peat with Cement, Polypropylene Fibers and Air Curing Technique, Global Journal of Researches in Engineering, Vol. 10, Issue 1 (Ver1.0), (2010), pp: 9-15. 
VOLUME 20 | NUMBER 2 | January 2021

\section{Biographies}

Mohamad Niizar Abdurahman is a Senior Civil Engineer at Public Works Department of Malaysia. Currently he is also pursuing his $\mathrm{PhD}$ in the field of geotechnics in Universiti Tun Hussein Onn Malaysia. His area of research interest includes Geotechnical engineering and soft soil engineering, particularly peat.

Ts. Dr. Adnan Zainorabidin is an Associate Professor in Universiti Tun Hussein Onn Malaysia. Graduated from University of East London with $\mathrm{PhD}$ in Civil Engineering and specialized in peat soil. His field of interest are from various fields in Geotechnical Engineering, Foundation Engineering, Highway Engineering and Soft Soil Engineering (Peat Soil Specialization).

Ts. Ir. Dr. Azman Kassim is a Professor at the School of Civil Engineering, Faculty of Engineering, UniversitiTeknologi Malaysia. Professor Dr. Azman earned his Bachelor of Science in Civil Engineering from University of Miami, United State of America in 1988 and Master of Engineering in Engineering Geology from Universiti Teknologi Malaysia (1996). He completed his PhD at Universiti Teknologi Malaysia in 2011. Professor Dr. Azman's fields of interest are Slope Engineering, Unsaturated Soil Mechanics, Soil Properties, Instrumentation and Geotechnical Modeling. He is currently a Professional Engineer, registered to Board of Engineer Malaysia (BEM) since 2006, a Corporate Member of Institute of Engineers Malaysia (2010), Professional Technologist registered with Malaysian Board of Technologist and a Member of Associate Asean Engineer (2013). He has published over 100 journal and conference research papers and has supervised more than 40 postgraduate students. Presently, Prof. Ts. Ir. Dr. Azman's research studies have focused on bringing unsaturated soil mechanics into slope engineering practice. Prof. Ts. Ir. Dr. Azman's significant contribution has been made in many of the classic areas of unsaturated soil systems which mainly in the stability of slopes and flow through saturated-unsaturated soil slope systems. He has devoted his professional effort towards meeting the needs associated with furtherance and implementation of unsaturated soil mechanics into geotechnical engineering practice; both in Malaysia and around the world.

Kasbi Basri is a PhD student at Universiti Tun Hussein Onn Malaysia. Graduated Bachelor's degree (Honours) and Master's degree in Civil Engineering from Universiti Tun Hussein Onn Malaysia. His area of research interest includes Geotechnical engineering, Geophysical engineering and soft soil engineering. 